\title{
ORIGINAL
}

\section{Production of Fatty Acids from 1-Propanol in Pseudomonas sp}

\author{
Hisaaki YaGI, Toshihiro YoKochI, Yasushi KamisaKa, Masakazu YamaoKA, \\ Toro NAKAHARA, and Osamu SuzUKI \\ Biological Chemistry Division, National Chemical Laboratory for Industry \\ (Tsukuba-shi, Ibaraki-ken, =305)
}

\begin{abstract}
Pseudomonas sp (ATCC 12085) grown in a medium containing 1-propanol produced pentadecanoic $\left(C_{15}\right)$, heptadecanoic $\left(C_{17}\right)$, heptadecenoic $\left(C_{17: 1}\right)$, and methyleneheptadecanoic acids $\left(C_{18 c y c}\right)$, a cyclopropane fatty acid. The ratio of these fatty acids except for heptadecenoic acid to all fatty acids increased with the growth of Pseudomonas. Maximum concentrations of these fatty acids were obtained at $0.5 \%$ 1-propanol. The fatty acids were also produced in the presence of sodium propionate instead of 1propanol. The production of odd-numbered fatty acids and methylene-heptadecanoic acid by Pseudomonas sp can be explained based on the intermediary propionyl-CoA from 1-propanol and propionic acid.
\end{abstract}

\section{Introduction}

The effect of $n$-alcohols on fatty acid composition of $E$. coli ${ }^{1) \sim 4)}$, Bacillus $^{5}$ and Clostridium $^{6}$ ) has been previously studied. These results showed that the concentration of individual fatty acids present was dependent on the alcohols employed, however these alcohols were not assimilated.

Pseudomonas sp (ATCC 12085) produced $\mathrm{C}_{16}, \mathrm{C}_{16: 1}, \mathrm{C}_{18: 1}$, and cyclopropane acids $\left(\mathrm{C}_{17 \mathrm{cyc}}\right.$ and $\left.\mathrm{C}_{19 \mathrm{cyc}}\right)$ when grown in a medium containing peptone and yeast extract. $\mathrm{C}_{16}$, $\mathrm{C}_{16: 1}$, and $\mathrm{C}_{18: 1}$ were synthesized from acetyl-CoA (ACP) which is a primer of fatty acid synthesis and malonyl-ACP supplying $\mathrm{C}_{2}$ unit to acyl-ACP. As the growth advanced, $\mathrm{C}_{17 \mathrm{cyc}}$ and $\mathrm{C}_{19 \mathrm{cyc}}$ were produced as the result of methyl transfer reaction of $S$-adenosyl-L-methionine onto the double bond of $\mathrm{C}_{16: 1}$ and $\mathrm{C}_{18: 1^{7), 8}}$.

Key words : Pseudomonas sp, 1-propanol, pentadecanoic acid, heptadecanoic acid, heptadecenoic acid, methyleneheptadecanoic acid

Abbreviation : ACP, acyl carrier protein

Correponding author : Hisaaki YAGI
Aside from the fatty acids mentioned above, this strain was capable of producing $\mathrm{C}_{15}, \mathrm{C}_{17}, \mathrm{C}_{17: 1}$ and $\mathrm{C}_{18 \mathrm{cyc}}$ in the presence of 1-propanol. This fact indicated that after oxidation 1-propanol was converted to propionyl-CoA (ACP) which was used as a primer for production of odd-numbered fatty acids $\left(\mathrm{C}_{15}, \mathrm{C}_{17}, \mathrm{C}_{17: 1}\right)$. In the next step, $\mathrm{C}_{17: 1}$ was converted to $\mathrm{C}_{18 \mathrm{cyc}}$ by the methyl transfer from $S$-adenosyl-L-methionine.

Fatty acid synthesis from $n$-alcohols, whose number of acyl chain is longer than 3 , has not been studied extensively. Therefore production of odd-numbered and cyclopropane fatty acids from 1-propanol and propionic acids was hereby studied.

\section{Materials and Methods}

\section{Organism and cultivation}

All experiments were performed with Pseudomonas sp (ATCC 12085) grown at 25 ${ }^{\circ} \mathrm{C}$. Polypepton which was purchased from Nihon Seiyaku (Tokyo, Japan) was used for peptone. Yeast extract was purchased from Nakarai Tesque (Kyoto, Japan). Tropic 
Marin was purchased from Aquarientechnik (Wartenberg, Germany) to prepare artificial sea water. The basal medium contained $3 \mathrm{~g}$ peptone and $1 \mathrm{~g}$ yeast extract in $1 \mathrm{~L}$ of artificial sea water. Buffered medium was prepared by adding $200 \mathrm{mM}$ HEPES in the basal medium before sterilization ( $\mathrm{pH}$ 7.5). The medium containing 1-propanol was prepared by adding this alcohol through a membrane filter with $0.2 \mu \mathrm{m}$ pore size to the medium after sterilization. The medium containing sodium acetate or sodium propionate was prepared by adding each reagent to the basal medium before sterilization. Pseudomonas sp was grown in pre-culture flask and subsequently inoculated into 500 $\mathrm{mL}$ flask containing $150 \mathrm{~mL}$ of the medium. Cell growth was measured with turbidimeter at $650 \mathrm{~nm}$ with $\mathrm{pH}$ measurement at the same time.

\section{Extraction of lipids}

Cells were collected after centrifugation and washed with a $0.8 \% \mathrm{NaCl}$ solution and suspended in approximately $0.5 \mathrm{~mL} \mathrm{NaCl}$ solution $(0.8 \%)$. Two milliliters of a $\mathrm{CHCl}_{3}$ $-\mathrm{MeOH}$ solution $(1: 2 \mathrm{vol} / \mathrm{vol})$ was added and stirred using a vortex, where $6 \mathrm{~mL}$ $\mathrm{CHCl}_{3}$ and $2 \mathrm{~mL}$ saturated $\mathrm{NaCl}$ solution was added. After stirring the mixture, the $\mathrm{CHCl}_{3}$ layer was separated. Any water present was removed by addition of sodium sulfate, whose mixture was then filtered and concentrated for fatty acid analysis.

\section{Fatty acid analysis}

Fatty acid methyl ester was prepared by the following procedure : a $0.2 \mathrm{~mL}$ lipid extract in $\mathrm{CHCl}_{3}$ was saponified with $0.5 \mathrm{~mL}$ of $0.5 \mathrm{~N} \mathrm{NaOH}-$ methanol solution at $80^{\circ} \mathrm{C}$ for $5 \mathrm{~min}$ and cooled in ice. The solution was then esterified with $\mathrm{BF}_{3}$ in $\mathrm{MeOH}$ at $80^{\circ} \mathrm{C}$ for 5 min. The fatty acid methyl esters were extracted by adding $0.7 \mathrm{~mL}$ hexane and a 1 $\mathrm{mL}$ saturated $\mathrm{NaCl}$ solution. The hexane layer was then examined by GC and GCMS. Shimadzu GC 8A equipped with CPS-2 bonded capillary column was used for GC, while HP 5971 A and HP 5890 for GC-MS. Individual fatty acid methyl esters of the lipid extract were identified by their retention time and mass spectral fragmentation pattern. With the equipment used, $\mathrm{C}_{18: 1}$ $(n-7)$ and $\mathrm{C}_{18 \mathrm{cyc}}(n-6)$ were not separated. To obtain the ratio of $\mathrm{C}_{18: 1}(n-7)$ and $\mathrm{C}_{18 \mathrm{cyc}}$ $(n-6)$, mild hydrogenation was done (5\% $\mathrm{Pd} / \mathrm{C}$, for $5 \sim 10 \mathrm{~min}$ at room temperature). After filtration and removal of the solvent used (diethyl ether) under nitrogen stream, the product was diluted with a small amount of hexane, and was injected into GC. After the procedure, $\mathrm{C}_{18: 1}$ was converted to $\mathrm{C}_{18}$ with $\mathrm{C}_{18 \mathrm{cyc}}$ intact. Subsequently we could obtain the ratio of $\mathrm{C}_{18: 1}(n-7)$ and $\mathrm{C}_{18 \mathrm{cyc}}(n-6)$. Positions of the double bond and cyclopropane ring were determined by picolinyl method ${ }^{9), 10)}$.

\section{Results}

Fig. -1 shows the difference in the fatty acid composition of lipid extract from the whole cell grown in basal medium and in 1-propanol-supplemented buffered medium. $\mathrm{C}_{15}, \mathrm{C}_{17}, \mathrm{C}_{17: 1}$, and $\mathrm{C}_{18 \mathrm{cyc}}$ were produced only in the latter medium.

The growth at different 1-propanol concentrations from $0 \%$ to $3 \%$ are shown in Fig.-2. There was no apparent effect on the

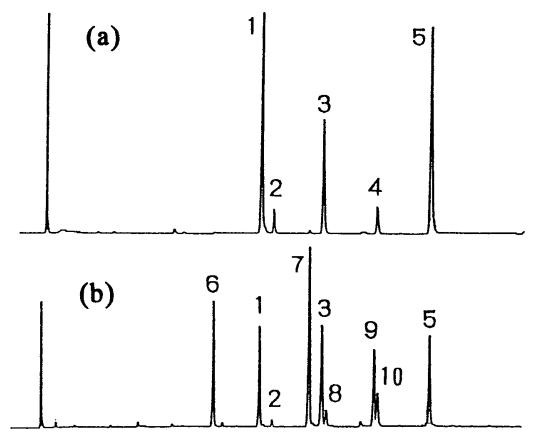

Cell was grown in the basal medium (a) and the buffered medium containing $0.5 \%$ 1-propanol (b).

1 , hexadecanoic acid, C16; 2, 9 - hexadecenoic acid, C16:1 $(n-7)$;

$3,9,10$ - methylenehexadecanoic acid ( 8 - ( 2 - hexyl - 1 - cyclopropyl ) octanoic acid),C17cyc $(n-7) ; 4,11$ - octadecenoic acid, C18:1 ( n-7); 5, 11, 12 - methyleneoctadecanoic acid ( 10 - ( 2 - hexyl - 1 - cyclopropyl) decanoic acid ), C19cyc $(n-7) ; 6$, pentadecanoic acid, C15 ;

7, heptadecanoic acid, $\mathrm{C} 17 ; 8$, heptadecenoic acid, $\mathrm{C} 17: 1$;

9, 9, 10 - methyleneheptadecanoic acid ( 8 - ( 2 - heptyl - 1 - cyclopropyl ) octanoic acid ), C18cyc $(n-8) ; 10,11,12$ - methyleneheptadecanoic acid ( 10 - ( 2 pentyl - 1 - cyclopropyl ) decanoic acid ), C18cyc $(n-6)$ The peak 3, 5, 9, and 10 are cyclopropane acids. The peak 10 contained both C18: $1(n-7)$ and C18cyc $(n-6)$ bacause of their inseparable nature.

Fig.-1 Gas chromatogram of fatty acid methyl esters derived from the whole cell lipid 


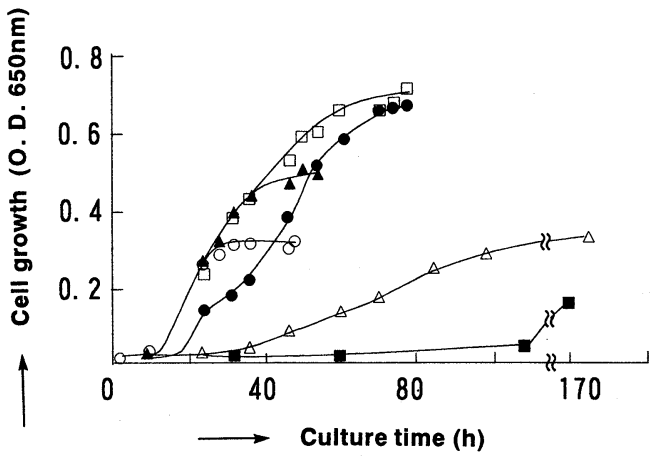

Cell was grown in the buffered medium containing 1-propanol of which concentrations were $0 \%(\bigcirc), 0.2 \%(\Delta), 0.5 \%(\square), 1.0 \%(\bullet), 2,0 \%$ $(\triangle), 3.0 \%(\square)$

Fig.-2 Cell growth in various 1-propanol concentration.

growth rate below $0.5 \%$ concentration. At concentrations above $1 \%$, the growth initiation was delayed and the lower growth rate was indicated. Final cell mass took maximum value at 0.5 and $1.0 \%$ concentrations.

Fatty acid composition of lipid extract harvested at the end of culture in Fig. -2 is shown in Fig. -3 . Ratio of $\mathrm{C}_{15}$ and $\mathrm{C}_{18 \text { cyc }}$ to all the fatty acids was maximum at $0.5 \%$ 1-propanol. The maximum for $\mathrm{C}_{17}$ was at both 0.5 and $1.0 \%$ concentrations. Decreases of the ratio of $\mathrm{C}_{15}, \mathrm{C}_{17}, \mathrm{C}_{18 c y c}$ were exhibited at 1-propanol concentrations above $1 \%$. Reversely, ratios of $\mathrm{C}_{16}$ and $\mathrm{C}_{19 \mathrm{cyc}}$ became the minimum at $0.5 \% 1$-propanol. $\mathrm{C}_{17 \mathrm{cyc}}$ was not so changed. Only small amounts of $\mathrm{C}_{16: 1}$ and $\mathrm{C}_{18: 1}$ were detected because these were easily converted to $\mathrm{C}_{17 \mathrm{cyc}}$ and $\mathrm{C}_{19 \mathrm{cyc}}$.

Relationship of fatty acid composition and growth phase is shown in Fig. -4 . The ratio of fatty acids produced from 1-propanol was small at the early stage and increased as the growth progressed. Quantities of $\mathrm{C}_{16}$, $\mathrm{C}_{16: 1}$, and $\mathrm{C}_{18: 1}$ decreased with increase of the growth while the ratio of $\mathrm{C}_{19 c y c}$ was unchanged.

Fig. -5 shows the production of $\mathrm{C}_{15}, \mathrm{C}_{17}$, and $\mathrm{C}_{18 \text { cyc }}$ when sodium propionate was added instead of 1-propanol. Concentrations of $\mathrm{C}_{15}, \mathrm{C}_{17}, \mathrm{C}_{18 \mathrm{cyc}}(n-8)$, and $\mathrm{C}_{18 \mathrm{cyc}}(n-6)$ in $100 \mathrm{mM}$, sodium propionate were $16.5,23.2$, 8.1 , and $5.7 \%$, respectively. These values were almost the same to those obtained with
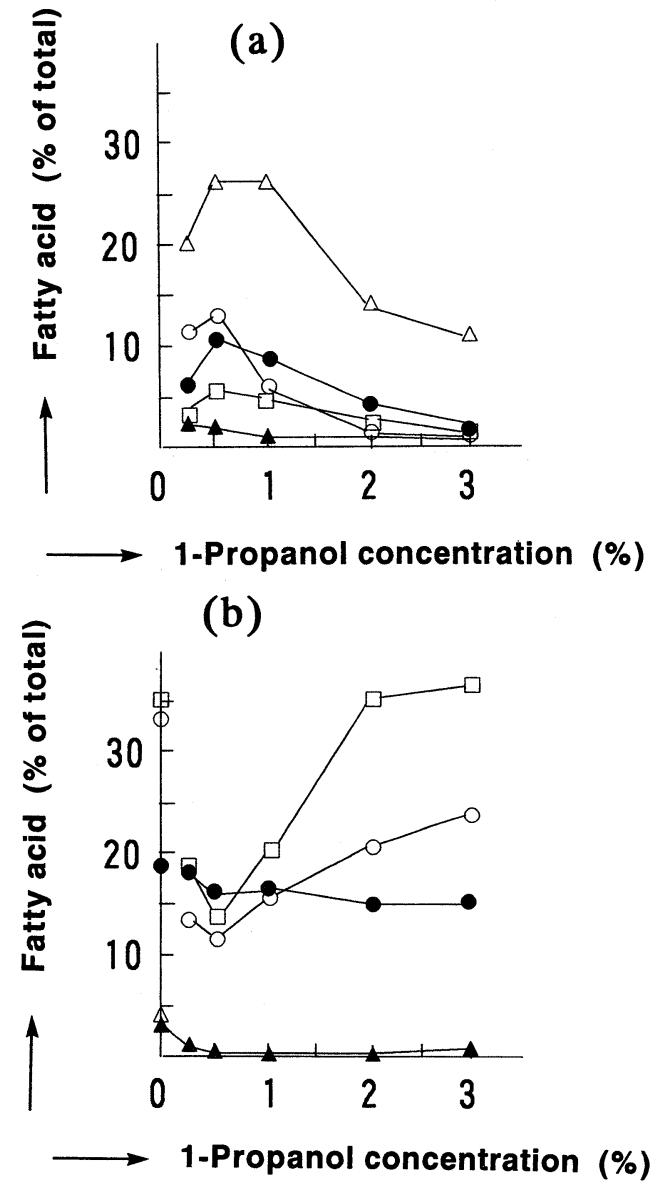

Cell was harvested at the end of culture shown in Fig. - 2.

(a) Fatty acids formed from 1 - propanol; $\mathrm{C} 15(\bigcirc), \mathrm{C} 17(\triangle)$.

C17: 1 (A), C18cyc $(n-8)(\bigcirc), C 18 c y c(n-6)(\square)$

(b) Fatty acids other than the ones shown in (a); $\mathrm{C} 16(\bigcirc)$, C16:1 $(n-7)(\mathbf{\Delta}), \operatorname{C17cyc}(n-7)(\bigcirc), C 18: 1(n-7)(\triangle)$, C19cyc $(n-7)(\square)$

Fig.-3 Fatty acid composition at various 1propanol concentration.

\section{$0.5 \% 1$-propanol.}

Comparison of the growth in sodium acetate-, 1-propanol-, and sodium propionate-supplemented medium is shown in Fig. -6. In $0.5 \%$ 1-propanol (approximately $66 \mathrm{mM}$ ) supplemented medium, growth rate was similar to that of the basal medium, and final cell mass was larger than the one obtained in the basal medium. In sodium propionate-supplemented medium, the growth initiation was delayed and the growth rate was lower than the one in basal medium, however final cell mass was larg- 

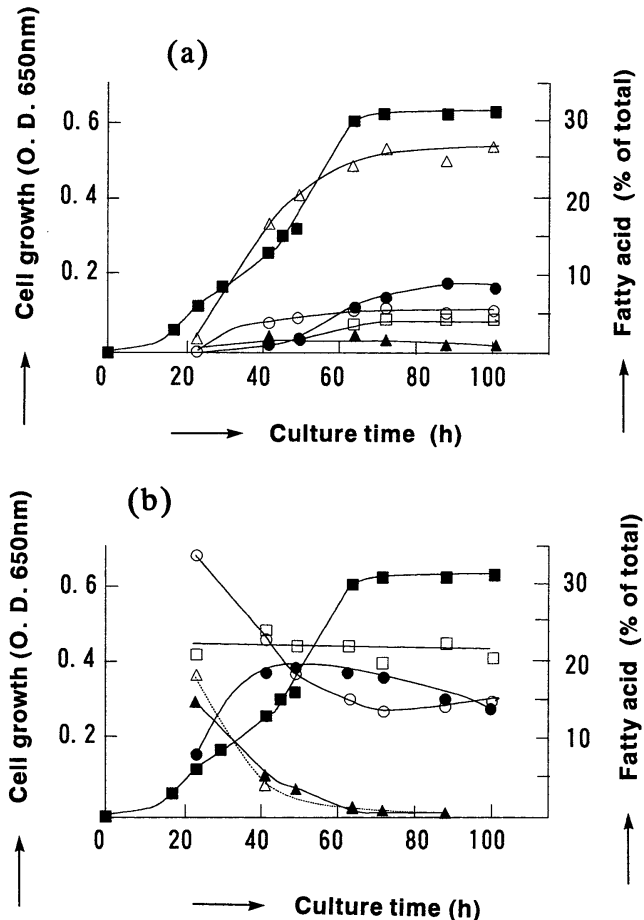

Cell was grown in the buffered medium containing $1.0 \%$ 1-propanol. The cell growth is represented by the symbol $(\boldsymbol{\square})$

(a) Fatty acids formed from 1-propanol. Symbols of fatty acids are the same

as the ones shown in Fig. - 3 (a).

(b) Fatty acids other than the ones shown in (a). Symbols of fatty acids are the same as the ones shown in Fig. - 3 (b).

Fig. -4 The fatty acid composition change according to the cell growth.

er. In sodium acetate-supplemented medi$u m$, the growth rate and final cell mass was higher and larger than the ones in basal medium. ${ }^{11), 14), 15)}$.

\section{Discussion}

The ability of Pseudomonas sp (ATCC $12085)$ to produce $\mathrm{C}_{15}, \mathrm{C}_{17}, \mathrm{C}_{17: 1}$, and $\mathrm{C}_{18 \mathrm{cyc}}$ in the presence of 1-propanol is hereby presented. This finding indicates that the fatty scid synthetase (FAS) system of this strain can utilize propionyl-CoA (ACP) as well as acetyl-CoA (ACP) for primer. The FAS system of the other bacteria was reported to be able to utilize various acyl-CoAs as a primer in vitro ${ }^{11), 14), 15)}$. It is thought that $\mathrm{C}_{18 \mathrm{cyc}}(n-6)$ and $\mathrm{C}_{18 \mathrm{cyc}}(n-8)$ are formed from $\mathrm{C}_{17: 1}(n-6)$ and $\mathrm{C}_{17: 1}(n-8)$, respectively with $S$-adenosyl-L-methionine. Therefore, the FAS system of this strain can form a double bond at the position of $n-6$ and $n-8$

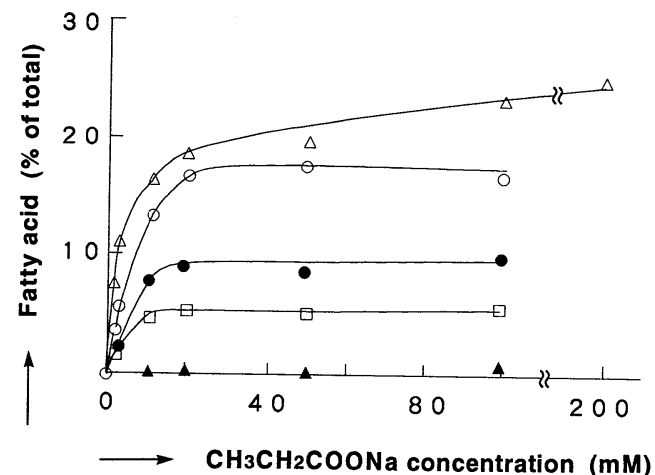

Cell was grown in the basal medium containing sodium propionate. Symbols of fatty acids are the same as the ones shown in Fig. - 3 (a).

Fig.-5 Fatty acid concentration formed from propionic acid at various sodium propionate concentration.

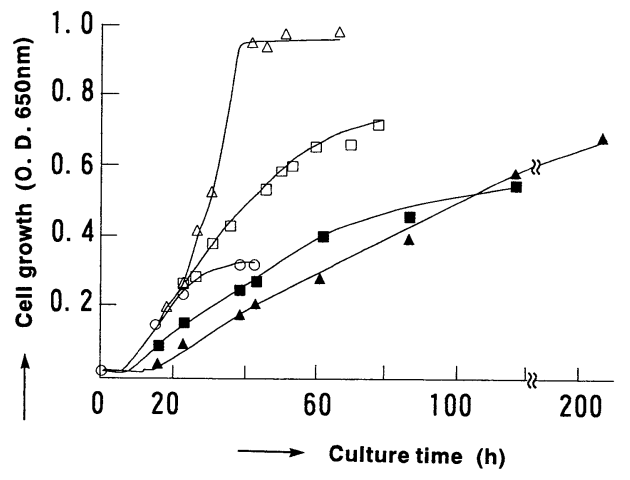

Cell was grown in the basal medium $(O)$ containing $100 \mathrm{mM}$ sodium acetate $(\triangle), 50 \mathrm{mM}$ sodium propionate $(\mathbf{\square})$, or $100 \mathrm{mM}$ sodium propionate $(\boldsymbol{\Delta})$, and in the buffered memium containing $0.5 \%$ 1-propanol ( $\square$ ).

Fig.-6 Comparison of the growth in sodium acetate-, 1-propanol-, and sodium propionate-supplemented media.

by the $\beta, \quad \gamma$-dehydration of 3-hydroxynonanoyl-ACP and 3-hydroxyundecanoyl$\mathrm{ACP}$ in the process of fatty acid synthesis if a double bond is formed via the anaerobic pathway. However $\mathrm{C}_{17: 1}(n-6)$ and $\mathrm{C}_{17: 1}$ $(n-8)$ could not be properly identified. One $\mathrm{C}_{17: 1}$ peak (peak no. 8 ) in Fig. -1 was so small that its double bond position could not be determined. The presence of another $\mathrm{C}_{17: 1}$ peak could not be ascertained because its peak may have overlapped with that of $\mathrm{C}_{17 \text { cyc }}$ beside probably being present in small amount.

In the absence of 1-propanol this strain did not produce odd numbered-fatty acids, showing that propionyl-CoA could not be 
synthesized from the materials present in the basal medium. On the other hand, in the presence of 1-propanol this strain oxidized 1-propanol to relieve its effect and the product was further converted to propionyl-CoA which is the primer for producing odd numbered fatty acid, and subsequently the cells utilized propionyl-CoA for the fatty acid synthesis. Moreover, enhancement of final cell mass in the presence of 1-propanol indicated that the supply of a primer for the fatty acid synthesis was one of the limiting step in the basal medium. A small amount of odd-numbered fatty acids and $\mathrm{C}_{18 c y c}$ derived from 1-propanol were present in the early growth phase, which was probably related to the alcohol dehydrogenase activity which increased accordingly with growth (unpublished data).

In the presence of sodium propionate, odd numbered-fatty acid and $\mathrm{C}_{18 \mathrm{cyc}}$ were also produced. In the experiment with $E$. coli ${ }^{12)}$, $\mathrm{C}_{15}$ and $\mathrm{C}_{17}$ were also produced in the presence of propionic acid. In the present paper, the growth rate in sodium propionate-supplemented medium was lower than that in 1-propanol (Fig. -6). This is explained as follows. The conversion of propionic acid to propionyl-CoA consumed ATP and does not produce NADH. On the other hand, dehydrogenation of 1-propanol produces NADH. Assimilation of propionic acid is, therefore, less advantageous in the aspect of the energy production. The reason for the better growth in sodium acetate-supplemented medium is that acetic acid can enter into TCA cycle via acetyl-CoA and is used for production of ATP and other organic compounds as well as the fatty acid synthesis from acetyl-CoA.

We know only one report with Streptococcus salivalius ${ }^{13}$ ) on the fatty acid synthesis from 1-alcohols with more than 3 carbon chain. There is quite a number of bacteria that can assimilate such alcohols as well as methanol and ethanol. A part of these bacteria possibly produce fatty acids from $n$-alcohol.

(Received March 13, 1992)

\section{Reference}

1) L.O. Ingram, J. Bacteriol., 125, 670 (1976).

2) K.H. Sullivan, G.D. Hegeman, and E.H. Cordes, J. Bacteriol., 138, 133 (1979).

3) K.M. Dombec and L.O. Ingram, J. Bacteriol., 157, 233 (1984).

4) L.O. Ingram and N.S. Vreeland, J. Bacteriol., 144, 481 (1980).

5) D. Rigomier, J.-P. Bohin, and B. Lubochinsky, J. Gene. Microbiol., 121, 139 (1980).

6) A.A. Herrero, R.F. Gomez, and M.F. Roberts, Biochim. Biophys. Acta, 693, 195 (1982).

7) A.J. Fulco, Prog. Lipid Res., 22, 133 (1983).

8) P.H. Buist and J.M. Findlay, Can. J. Chem., 63, 971 (1985).

9) D.J. Harvey, Biomed. Mass Spectrom., 11, 187 (1984).

10) D.J. Harvey, Biomed. Mass Spectrom., 11, 340 (1984).

11) A. Kawaguchi, N. Uemura and S. Okuda, J. Biochem., 99, 1735 (1986).

12) L.O. Ingram, L.S. Chevalier, E.J. Gabbay, K.D. Ley, and K. Winters, J. Bacteriol, 131, 1023 (1977).

13) L.M. Markevics, K.K. Kan, L. Rathsam, L.W. Turner, and N.A. Jacques, J. Gene. Microbiol., 133, 1543 (1987).

14) T. Kaneda and E.J. Smith, Can. J. Microbiol., 26, 893 (1980).

15) T. Kaneda, E.J. Smith, and D.N. Naik, Can. J. Microbiol., 29, 1634 (1983).

Pseudomonas sp における 1-プロパノールからの脂肪酸の生産

$$
\begin{aligned}
& \text { 八木久彰・横地俊弘・神坂 泰 } \\
& \text { 山岡正和・中原東郎・鈴木 修 } \\
& \text { 化学技術研究所 (于305つくば市東 1-1) }
\end{aligned}
$$

Pseudomonas sp (ATCC 12085) は, 培地に 1-プ ロパノールを添加したときに, 新たに $\mathrm{C}_{15}, \mathrm{C}_{17}, \mathrm{C}_{17: 1}$, $\mathrm{C}_{18 \mathrm{cyc}}$ の脂肪酸を合成した。全脂肪酸に対する $\mathrm{C}_{15}$, $\mathrm{C}_{17}, \mathrm{C}_{18 \mathrm{cyc}}$ の比率は増殖とともに増大し, 1-プロパ ノール濃度が $0.5 \%$ の時に最も高かった。1-プロパ ノールの代わりにプロピオン酸ナトリウムを加えたとき も，これらの脂肪酸は同じように合成された。これらの 実験結果は, Pseudomonas sp が, 1-プロパノールに 由来するプロピオニル-CoA ( $\mathrm{ACP})$ をプライマーとし て, $\mathrm{C}_{15}, \mathrm{C}_{17}, \mathrm{C}_{17: 1}, \mathrm{C}_{18 \mathrm{cyc}}$ の脂肪酸を合成すること を示している。

連絡者：八木久彰 